\title{
Environmental Management in the Printing Industry
}

\author{
Femi Kayode \\ Department of Industrial Design, The Federal University of Technology, P.M.B. 704, Akure, \\ Ondo State, Nigeria \\ Email: olfok174@yahoo.com
}

Ogunlade B. A.

Department of Fine and Applied Art, Ladoke Akintola University, Ogbomoso, Oyo

State

Accepted: July 17, 2012 Published: September 01, 2012

Doi:10.5296/jsr.v3i2.2328 URL: http://dx.doi.org/10.5296/jsr.v3i2.2328

\begin{abstract}
The 1999-Revised edition of the National Policy on the Environment, section 1.0 states that: "Nigeria is committed to a national environmental policy that will ensure sustainable development based on proper management. The paper sees this position as the best way to have an environment that is business-friendly. The printing industry, like any other organization cannot thrive successfully under an environment abused by man-made or artificial phenomena. All the assets and liabilities of nature meant to be enjoyed or otherwise by the printing industry are also important factors when it comes to environment management. The entire stakeholders of the printing industry such as the shareholders/employer, employees, customers, suppliers/contractors and the creditors as well as the Government have one responsibility or the other to perform. The paper therefore opines a two-way relationship between man and the environment, whereby man must handle the environment with sympathetic consideration and the environment too, creatively yield. The paper also suggests to the printing industry and explains, benchmarking as a highly organized technique of managing the environment better.
\end{abstract}

Keywords: Environment, Legislation, Printing Industries, Pollution, Protection. 


\section{Introduction}

One technique often used to get the best out of the employees is noted in Banabo and Banabo (2011) as motivation but for the environment, it is good operational and management system. The National Policy on the Environment (1999) (Revised edition) has it that Nigeria is committed to a National Environmental Policy that will ensure sustainable development based on proper management of the environment. It is therefore inferred in Omotoso (2004) that sustainable industrial activities obviously depend on well-managed operational environment. The printing activities are not exempted. Where there is environmental sanitation and protection, most environmental problems can be avoided. Such elements as air, land and water pollutions caused by indiscriminate discharge of industrial wastes, especially useless colour/ink, chemicals, liquid solvents, radioactive and junked materials become less severe if not completely abated. The problems of mismanagement of the environment are observed by the World Development Report (1992) to vary from one environment to another or from one country to the other. It can as well vary with the stage of development of each country, the structure of their economies and the environmental policies of that country. Resultant challenges that are likely to confront man from environmental mismanagement are retardation of economic developments, inadequate sanitation and clean water, inhalation of polluted air, contamination of materials, ill health and land degradation to mention just a few. For this reason, adequate management of the environment ought to be taken seriously. An aggressive Environmental Management System (EMS) in the country is of the essence which means a systematic and integrated approach to managing and controlling environmental impacts and ensuring compliance with the various environmental regulations. Along this line, the paper will be looking at the production behavior and atmospheric impact of the printing industry as seen against the backdrop of these legal regulations, and government policies. Rewards for compliance and sanctions against non-conformity are also implied. More printing industries should also be sensitized on the judicious utilization of the atmospheric resources so that the earth would continue to tolerate and support man and his enterprise.

\section{Environmental Management System (EMS)}

Interest in environmental management has grown since the early 1970s (Park 1997). The environment in which human activities are carried out comprises of man, ecological, physiochemical and socio-cultural factors. The ecological factors are natural phenomena like vegetation, hills, mountains, and large bodies of water, landmasses and animals. The physiochemical are all physical assertions and effects of chemical outpourings like smokes, liquid and gaseous wastes and run-offs which industries discharge to pollute the atmospheric endowments, while the socio-cultural are the various government policy guidelines and societal norms which all citizens, including the industries have to comply with. Although, 
God gave man the moral freedom to subdue and have dominion over his environment, he continually abuses the privilege mainly by his physical activities. Remarking on desperate misuse, Nwanyanwu (2002) observes that man is unintentionally harming the environment in his efforts to use available resources to the best of his advantage.

The major significant environmental effects of printing industries are, discharged wastewater containing solvents and inks, contamination of the ground with solvent due to spillage during materials handling, generation of spoilage waste on various substrates during the printing process, generation of various 'make-ready' wastes during preparation. All these are phenomena mentioned in Isiguzo (1998) as pollution which make natural resources (air, water, land etc) unfit for man and sometimes other creatures. If the environment is as broad as to accommodate man, other creatures and their various activities, an organized management system will be pertinent. Good management system is a powerful tool that helps a business to succeed in meeting environmental challenges evolving from man's interaction with the ecological, physiochemical and socio-cultural features within a specific organizational structure. Industries may best accomplish this in two distinct ways. First by adopting an in-house managerial policy (internally formulated) of its own and second, by following the guidelines stipulated by government, or its accredited agencies like the Environmental Protection Agencies (FEPA/SEPA), National Agency for Foods, Drug Administration and Control (NAFDAC), and Environmental Sanitation Task Force (externally formulated) to mention but a few.

\section{Legislative Implications}

The need has arisen for graphic workers and printers to be conscious of the environment. Hygienic methods of production, harmless manner of waste disposal and the ability of products to effectively perform its functions without damaging effects on the natural environment reside in this challenge. Lowry (1997) attests that there is a wide range of legislation associated with these responsibilities, which relates (as with craftwork) to the environment, health and safety, and consumer protection. The print working environment, by legislative implications is to consider the display of fire extinguishers in strategic points accessible to people in case of fire outbreak. Health and safety notices, such as instructions on tools and machinery handling, as well as enforcement of the use of safety materials like hand gloves, laboratory coat, goggles and hats available to the industries for compliance. Lowry (op cit) therefore highlighted that government legislation on environmental management covers the health and safety of workers at work. Areas such as Manual Handling Operations Regulations of 1992 and which was reviewed in 2009; Personal Projective equipment at work Regulations 1992; Electricity at work Regulations 1989 are statutorily enforced in Nigerian industries and factories. The Consumer protection Act of 1987 and which was revised in 2011 is also in place to bring sanity to the relationships between consumers and the industries.

There are many printing industries in Nigeria. The big ones such as Academy Press PLC, in 
Lagos, Onibonoje Press in Ibadan, Oyo State, GOAD Educational Publishers in Abeokuta, Ogun State have grown big to include publishing. Some others are Ola Awe Printers and Publishers in Akure, Ondo State and Baraka Press in Kaduna, Kaduna State to mention but a few. Apart from privately owned printing presses almost every state in the federation has its printing press. Nevertheless, all stakeholders connected with the printing industry (customers, employees, employers/shareholders and government) have their different roles to play. For instance, the customers should be well informed about the workings of a product. This has to do not only with the prospects but also with the possible hazards connected. It also has to do with how to handle the products and where the remnants of the used products, like the empty or packaging materials are finally discarded. In most cases, for other end users may need to collect them as waste for recycling. Interestingly, what seems 'waste' in one area starts a new life elsewhere.

Filani (1999) remarks that the word 'waste' does not necessarily mean a thing that can ever be useful, rather it is a term employed in relation to particular materials that have served their useful purposes for specific objectives. Recycling waste is thus, creative transformation and utilization of abandoned materials. Ademuleya (1999) corroborates the earlier scholar by noting that throughout history, artists have attempted to develop processes by which a material that is easy to shape can be transformed into something strong and lasting. Employees are charged with the responsibility of cultivating clean habits in and around the work environment. They are expected to comply with the various health and safety signs as well as potential hazard warnings provided by the company. Warnings may be in form of typographic inscriptions as in "DO NOT LITTER THE PREMISES", "KEEP OUR ENVIRONMENT CLEAN", and "DANGER! NO THOROUGHFARE" etc, or in the form of pictorial As part of management, the Personnel or Human Resources Department of the industry should have well-documented manual of continuous training information on safety measures, health practices and environmental protection procedures. Also, important is the fact that the management of the printing industry must ensure that all equipment are held in safe working condition with daily monitoring of the ambience of the total environment. All printed goods that proceed out of the industry must be quality-controlled and guaranteed durable and safe by the employers (Top management). According to Ademulegun (1999) the Industrial Safety Act (ISA) or the Health and Safety at WORK ACT (HSW) of 1974 which provides for the setting up of a Health and Safety Commission mandated that all person who design, manufacture, import or supply articles for use must ensure that they are designed and constructed so as to be safe and without risk to health when properly used. It also stipulates that manufacturers must carry out research, tests and examinations to ensure articles are safe and without risk to health. In a particular instance, NAFDAC was reported to have shut down two printing industries in Owerri, Nigeria for producing over 100 fake product labels for public consumption (The GUARDIAN, Monday, November 24, 2003). Besides, the HSW Act applies to all persons at work, employers, employees and all self employed persons, with the exception of domestic servants employed in a private household. Government provides the legal framework and policy guidelines on environmental matters. The yearly Environmental Audit Report (EAR) is one of the mechanisms that the government has put in 
place for monitoring the level of compliance of the industries.

\section{Impact Of The Printing Activities On The Environment}

The statement made in Ogedengbe and Oyedele (2007) that the environment is the most complex of all physical, chemical and biological factors which sustain sums up centuries of mankind's interaction with both the built and natural environment. Nigeria, in the words of Alakinde and Omole (2010) is among the third world nations that is witnessing an unprecedented growth in cities in recent time. The Influx of people and the infrastructural provisions that will take care of the population's physical activities pose a challenge. However, the environment is home and life; materials that must be discharged into it must be heavily censored. Nowadays, technological developments have involved the use of complex printing machines which generate both chemical and solid wastes. Discharge of solvents is one activity of the printing industries. Solvents are liquids that have dissolving power but most of them like petrol, kerosene, mentholated spirit and turpentine to mention but few have levels of inflammability when practically in contact with naked light. Most organic solvents, as well as thinner used to mix inks for quick drying effects are flammable and give off vapors that form explosive mixtures with air (Kuhn, 1986). Apart from being environmentally unfriendly when exposed, all solvents are chemicals which are practically irritating when allowed to evaporate into the air and inhaled. This position is justified by Hurst et al. (1963) and Kuhn (op cit), remark that "when using cleaning solvents such as turpentine, benzene or petrol care must be taken not to be used near on open flame or breathed in because of their poisonous vapors and explosive properties. The extent of irritation may be determined by the level of toxicity in a particular solvent and the quantity of it staked at a particular time. All organic solvents affect human organism and can damage it. The amount of damage caused depends on the amount absorbed in a given time span as well as on the toxicity of the solvent absorbed (Kuhn, 1986).

Disposal of used ink and liquid wastes is another effect which the printing industries have on the environment. Inks are one of the common organic solvents used for printing. When printing is done, solvents and other degreasing agents are needed to wash and keep clean all machine parts. However, when chemical wastes are disposed of in wrong channels, they may become environmentally disastrous as a result of its offensive odors and unpleasant inhalation. According to Prust (1989) taking in of ink vapors both at the level of breathing and at the level of body contact can be very harmful to heath or lead to injury that requires treatment by a doctor.

Discharge of paper and stone dusts, gasses and fumes are caused by fuelled printing machines and factory plants when in operation. They emit gaseous substances, fumes and discharge paper dusts. Prust (op cit) states that some commonly found hazardous chemical agents in the printing industry are carbon monoxide which is present in smokes produced by factory plants (and chimney) and ozone, which is also a gas of much concern. 


\section{The Damaging Effects}

Air Pollution: Industrial air pollution from a variety of chemicals has caused several large-scale tragedies that have attracted considerable attention (UNEP, 1989). Sulphur and carbon exhausts in the form of black smoke are common as a result of vehicular movements in urban commercial/residential areas and factories sited in urban industrial settlements. Industrial vehicles emit smoke while factory plants generate gasses, fumes and paper dusts. The damage on the environment can visibly be noticed in vehicular traffic on industrial premises and when equipment is put in motion. According to Feachem et al. (1992) air pollution generally is a growing problem in power plants and in the industry. He notices that this source of pollution gives rise to a varying mixture of chemicals and dusts that can damage the lungs and other organs depending on the actual compositions of the pollution.

Land Pollution: Land is the surface on which creative artistry and industrial activities are carried out. But when such an asset (land) is betrayed by human activities, the resultant effect could either be loss of natural endowments like vegetation and agriculture or loss of productivity. It could as well lead to loss of good health or even, life. Notably, paper off-cuts, trimmings, refuse dumps and junked materials as well as liquid wastes are major environmental effects of the printing industry. When corrosive chemical wastes are drained from the machine and released to run on the ground, they are capable of being partly evaporated into the air while the rest are left to spread over the surface of the soil. Thus, if care is not taken it could cause infertility of the soil, depletion of vegetables and loss of trees, which man depend on for agriculture and raw materials. Umeh et al. (1997) opines that land polluted by scattered wastes, refuse dumps and waste oils will result in a number of effects, which include breeding disease carriers (rat, flies, mosquitoes), killing of valuable or rare vegetation and wildlife by dumping of oil, rubble and similar materials as well as producing aesthetics effects and unsightliness resulting from litter of waste products.

Loss of good health: Printers and the public alike can contact skin and nerve diseases as a result of inhalation of the inherent toxic odour in inks/paints/colours. According to a study conducted in 1993 on two separate paint manufacturing industries producing resins, architectural and industrial coatings and powder paints in Australia, users of paints and inks need be put on regular health monitor because of damage of nervous system. Besides, respiratory testing showed that those working directly in paint or resin manufacture, and those such as maintenance and warehouse staff had significantly poorer lung function (by about 5-10 percent) than had laboratory or clerical personnel in the same firms. About 20 percent of the exposed workers complained of symptoms of shortness of breath, chest tightness and cough (Source-: International Federation of Chemical, Energy, Mines and Central Workers Union; 1996).

\section{Conclusion}

The write-up maintains that the printing industry in its management of the environment 
should look into the environmental policy guidelines and then strategize for effective operations. Good implementation of environmental management policy and sound operational instructions are highly essential for both office and factory staff. Evaluation and appraisal are imperative to add summative value to the management system in the printing world. This will result in improved relationship between man and the environment. However, while it is appreciated that waste generation and disposal procedures are inevitable in an occupational practice such as printing, it is suggested that the innocent environment (natural or built) should not be made to suffer the consequences.

\section{References}

Ademulegun F. (1999): Elements of Small Business Management Ikeja, Tees Tech Educational Publishers.

Ademuleya, B. A. (1999): "The use of petropolystyrene as a casting medium in sculptur", in Journal of Industrial Design and Technology (JINDEST), Vol. 1, No. 1.

Alakinde, M. K. and Omole, F. K. (2010): Socio-economic factors affecting solid waste generation and disposal in Ibadan metropolis, Nigeria. International Journal of Environmental Issues, 7(2), 1-13.

Banabo, E. and Banabo, K. C. (2011): A synopsis of motivational techniques in Nigerian work organizations. International Journal of Dvevelopment Studies, 6(1), 37-43.

Feachem R.G.A., Kjellstrom T, Murray C.J.L., Over M and Phillips M.A. (1992): The Health of Adults in the Developing World. London, Oxford University Press.

Filani, O. (1999): "Trend and Experiments on improvisation of art materials in Nigeria: Recycling from waste to wealth", in Journal of Industrial Design and Technology, (JINDEST) Vol. 1, No. 1

Hurst C.A. and Lawrence F.R. (1963): Letterpress Composition and machine work, Handbook to printing, London, Ernest Benin Limited.

Ibitoye, O. A. (2004): Conceptual issues in population, environment and sustainable development. In Economic and Social Issues in Population, Environment and sustainable Development in Nigeria, Ibitoye, O. A. (ed), 1-6.

International Federation of Chemical, Energy, Mine and General Workers' Union Magazine Vol.2, Pg 11, 1996.

Isiguzo, U.G. (1998): "Environmental Pollution and conservation" in Fundamentals of Citizenship Education Abeokuta, GOAD Educational Publishers. 
Kuhn, H. (1986): Conservation and Restoration of Works of Art and Antiquities - vol. 1, England, Butterworths.

National Policy on The Environment (Revised edition), 1999. Section 1.0.

Nigerian Environmental Study/Action Team (1991): “Nigeria's Threatened Environment National Profile", Ibadan, NEST.

Nwanyanwu, O.J., (2002): Man's Environment, Rapid study guide. Abeokuta, Goad Educational Publishers.

Ogedengbe, P. S. and Oyeleke, J. B. (2007): The effect of industrial pollution on residential neighbourhood: Amuwo-Odofin indusdterial layout, Lagos as a case study. In proceedings of the International Conference on Towards a Sustainable Built and Natural Environment,

Omotoso, O. (2004): Rural industrialization and regional development: A case study of Okitipupa oil palm mill. In Economic and Social Issues in Population, Environment and sustainable Development in Nigeria, Ibitoye, O. A. (ed), 64-66.

Park, C. (1997): The Environment - Principles and Applications. London, Routledge.

Prust, Z.A. (1989): Graphic Communications - The Printed Image. Illinois, The Good Heart - Willcox Company Inc., Publishers.

The GUARDIAN Newspaper, "NAFDAC shuts fake packaged water firms" Monday, November 24, 2003 page 14.

Umeh L.C., and Uchegbu S.N., (1997): Principles and procedures of Environmental Impact Assessment (EIA). Lagos, Computer Edge Publishers.

UNEP (United Nations Environmental Programme) (1989): Environmental Data Report. Oxford, Basil Blackwell Publishing Company. 